\title{
Opsonic requirements of Staphylococcus epidermidis
}

\author{
LUCILLA A. CLARK and C. S. F. EASMON \\ Department of Medical Microbiology, Wright-Fleming Institute, St Mary's Hospital Medical School, \\ London W2 1PG
}

\begin{abstract}
Summary. The opsonic requirements of 18 strains of Staphylococcus epidermidis were compared in pooled normal human serum and in peritoneal dialysate from patients undergoing continuous ambulatory peritoneal dialysis (CAPD). A serum concentration of $2.5 \%$ gave optimal opsonisation. The opsonisation of all strains was antibodyand complement-dependent, and there were no significant differences in the pattern of their opsonic requirements. Peritoneal-dialysis effluent from uninfected patients was a poor source of opsonins because of the low levels of immunoglobulin $\mathrm{G}$ and of the $\mathrm{C} 3$ component of complement it contained. Growth of $S$. epidermidis in peritonealdialysis effluent rather than in broth did not alter its opsonic requirements. Strains from patients undergoing CAPD and suffering from peritonitis were not more resistant to opsonisation and phagocytic killing than those from other sources.
\end{abstract}

\section{Introduction}

Peritonitis is one of the major complications of continuous ambulatory peritoneal dialysis (CAPD). Most infecting organisms come from the skin of patient or nurse, and Staphylococcus epidermidis is the most common cause of CAPD peritonitis. The main antibacterial defence of the peritoneal cavity is the opsonisation, phagocytosis and killing of invading bacteria, first by resident peritoneal macrophages and later by neutrophils that enter the peritoneal cavity as part of the early inflammatory response to infection. The large volumes of fluid used in dialysis tend to dilute available opsonins and reduce the concentration of peritoneal phagocytes, limiting the efficacy of this defence system (Verbrugh et al., 1983). An association between the level of opsonic activity and the incidence of peritonitis in CAPD patients has been shown by Keane et al. (1984). Duwe et al. (1981) have shown that the low $p \mathrm{H}$ and high osmolality of dialysis fluids may inhibit phagocytosis.

The opsonic requirements of bacteria of the same species or even the same serotype within a species may vary quite markedly (Hastings and Easmon, 1981); and resistance to opsonisation might be a determinant of virulence in the peritoneal cavity (Easmon and Glynn, 1976). We therefore investigated the opsonic requirements of $S$. epidermidis strains isolated from cases of CAPD peritonitis and endocarditis, and from the normal skin, with both

Received 19 Mar. 1985; revised version accepted 20 Aug. 1985. serum and peritoneal-dialysis effluent as a source of opsonins. We also examined the effect on opsonic requirements of growing $S$. epidermidis in dialysis effluent rather than in broth.

\section{Materials and methods}

\section{Bacteria}

Coagulase-negative staphylococci isolated from cases of CAPD peritonitis and from other sources were kindly supplied by Dr R. R. Marples, Division of Hospital Infection, Central Public Health Laboratory, Colindale, London. The strains used (listed in table I) were characterised at the Staphylococcal Reference Laboratory, also at Colindale, by the method of Baird-Parker (1963) as modified by Marples et al. (1978).

Bacteria were stored in liquid nitrogen and grown overnight at $37^{\circ} \mathrm{C}$ in either Brain Heart Infusion Broth (Lab M Ltd) or in peritoneal-dialysis effluent from uninfected patients that had been passed through an 0.45 $\mu \mathrm{m}$ membrane filter (Millipore Corp).

Before use the bacteria were washed twice in saline $0.9 \% \mathrm{w} / \mathrm{v}$ and resuspended to a concentration of $2-3 \times 10^{8}$ $\mathrm{cfu} / \mathrm{ml}$ in Hanks's Balanced Salt Solution without phenol red (HBSS; Gibco Ltd).

\section{Opsonins}

Pooled normal human serum (NHS) was obtained from six healthy adult volunteers. Portions of this $(0.5 \mathrm{ml}$ in volume) were stored at $-70^{\circ} \mathrm{C}$. Complement was inactivated by heating the serum at $56^{\circ} \mathrm{C}$ for $30 \mathrm{~min}$ (HHS). The classical pathway of complement was inacti- 
Table I. Serial numbers (and biotypes*) of strains of $S$. epidermidis used in this study

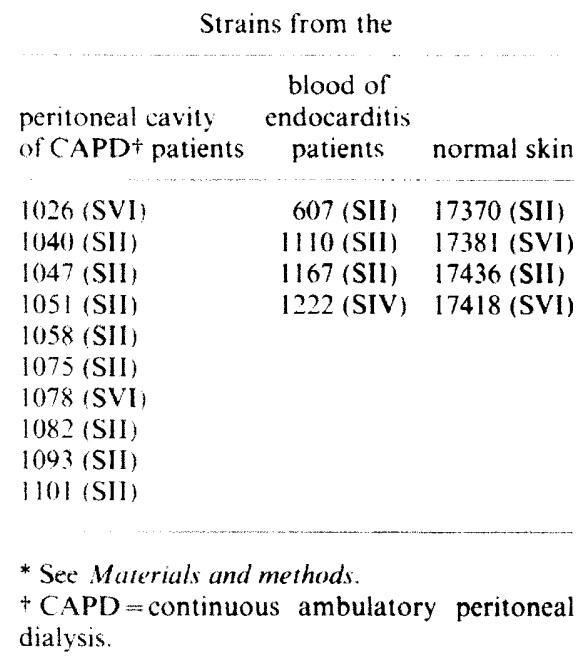

vated by treating NHS $(800 \mu \mathrm{l})$ with $200 \mu \mathrm{l}$ of a solution containing $100 \mathrm{~mm}$ magnesium chloride and $100 \mathrm{~mm}$ ethylene glycol tetra-acetate (Mg EGTA: Sigma Co.). $S$. epidermidis antibody was removed from NHS by absorbing three volumes of NHS with one volume of packed $S$. epidermidis (strain 1101) for $1 \mathrm{~h}$ at $4 \mathrm{C}$. Complement levels in absorbed serum were checked by testing on $\mathrm{C} 3 \mathrm{c}$ Radial Immunodiffusion Plates (Behring Co.) and by luminol-dependent chemiluminescence with zymosan as the opsonised particle (see below). Centrifuged, filtered, peritoneal-dialysis effluent from uninfected patients undergoing CAPD, and an immunoglobulin preparation (Sandoglobulin; Sandoz Co., Basle) made from pooled normal human plasma, were also used. Antibody-free baby-rabbit serum kindly provided by Dr D. Moreno, Wellcome Research Laboratories. Beckenham, was used as a source of complement.

\section{Polymorphonuclear leukocytes (PMN)}

PMN were separated from heparinised venous blood by incubation with dextran $6^{\circ} \mathrm{w} / \mathrm{v}$ in saline $0.9^{\circ} \mathrm{w} / \mathrm{v}$ for $45 \mathrm{~min}$. The leukocyte-rich plasma layer was removed and residual red cells were lysed by treatment for $10 \mathrm{~min}$ with $10 \mathrm{ml}$ of Tris-buffered ammonium chloride $0.83 \% \mathrm{w} / \mathrm{v}$. Cells were washed twice and resuspended to a concentration of $1.5 \times 10^{6} / \mathrm{ml}$ in HBSS supplemented with fetal calf serum $1 \% \mathrm{v} / \mathrm{v}$.

\section{Opsonisation}

Zymosan $(500 \mu \mathrm{l} ; 20 \mathrm{mg} / \mathrm{ml})$ was opsonised with $10 \%$ NHS. Similar volumes of bacteria were opsonised with serum or dialysis effluent. The reaction mixture was made up to $1 \mathrm{ml}$ with $\mathrm{HBSS}$ and was incubated at $37^{\circ} \mathrm{C}$ for 5 and $15 \mathrm{~min}$. The reaction was stopped by the addition of $1 \mathrm{ml}$ of HBSS at $4 \mathrm{C}$. Bacteria or zymosan were washed and resuspended in HBSS at the original concentration.

\section{Phagocytosis assays}

Microscopy. Opsonised bacteria were diluted 1 in 100 in HBSS, and $200 \mu \mathrm{l}$ of this suspension were incubated with an equal volume of $\mathrm{PMN}$ at $37^{\circ} \mathrm{C}$ for $15 \mathrm{~min}$, the tube being placed on a roller to ensure thorough mixing. Smears were prepared in a cytospin centrifuge (Shandon Co.). fixed with methanol and stained by Giemsa's method. Results were expressed as the percentage of PMN with ingested bacteria.

Luminol-dependent chemiluminescence. Suspensions of opsonised bacteria or zymosan $(200 \mu \mathrm{l})$ were added to 500 $\mu \mathrm{l}$ of PMN $\left(10^{6} / \mathrm{ml}\right)$ and $900 \mu 110^{-5} \mathrm{M}$ luminol (Sigma Co.) dissolved in dimethyl sulphoxide and then diluted in HBSS. The mixture was placed in the reaction chamber of a 1250 luminometer (LKB Co.) and the light generated recorded in $\mathrm{mV}$ at 10 - $\mathrm{s}$ intervals. The level of chemiluminescence after $15 \mathrm{~min}$ was recorded in each case.

\section{Complement and IgG levels}

These were measured on normal and low-range radial immunodiffusion plates for $\mathrm{C} 3$ and IgG (Behring Co.). The low-range plates were used for peritoneal-dialysis effluents.

\section{Results}

Preliminary work showed that phagocytosis of $S$. epidermidis was not increased by opsonisation with NHS at concentrations exceeding $2.5 \%$. At serum concentrations below this, the total amount of phagocytosis of all of the strains tested was considerably decreased; the results obtained with three of the strains, as measured by luminol-dependent luminescence and by microscopy, are illustrated in fig. 1 .

Fig. 2 shows the uptake of nine strains, of various biotypes and derived from several different bodysites, after opsonisation with $2.5 \%$ serum; similar results were obtained with the other nine strains tested. S. epidermidis was well opsonised by MgEGTA-chelated NHS but poorly opsonised by HHS. Increasing the serum concentration to $10 \%$ or even $20 \%$ did not improve the opsonic capacity of HHS (results not shown). These experiments demonstrated the importance of complement for the opsonisation of $S$. epidermidis.

We investigated the importance of antibody using serum absorbed with $S$. epidermidis cells and IgG prepared from pooled normal human plasma. Although, as expected, there was little difference between the uptake of bacteria opsonised for $15 \mathrm{~min}$ with $2.5 \%$ and $10 \%$ NHS, absorption with $S$. 

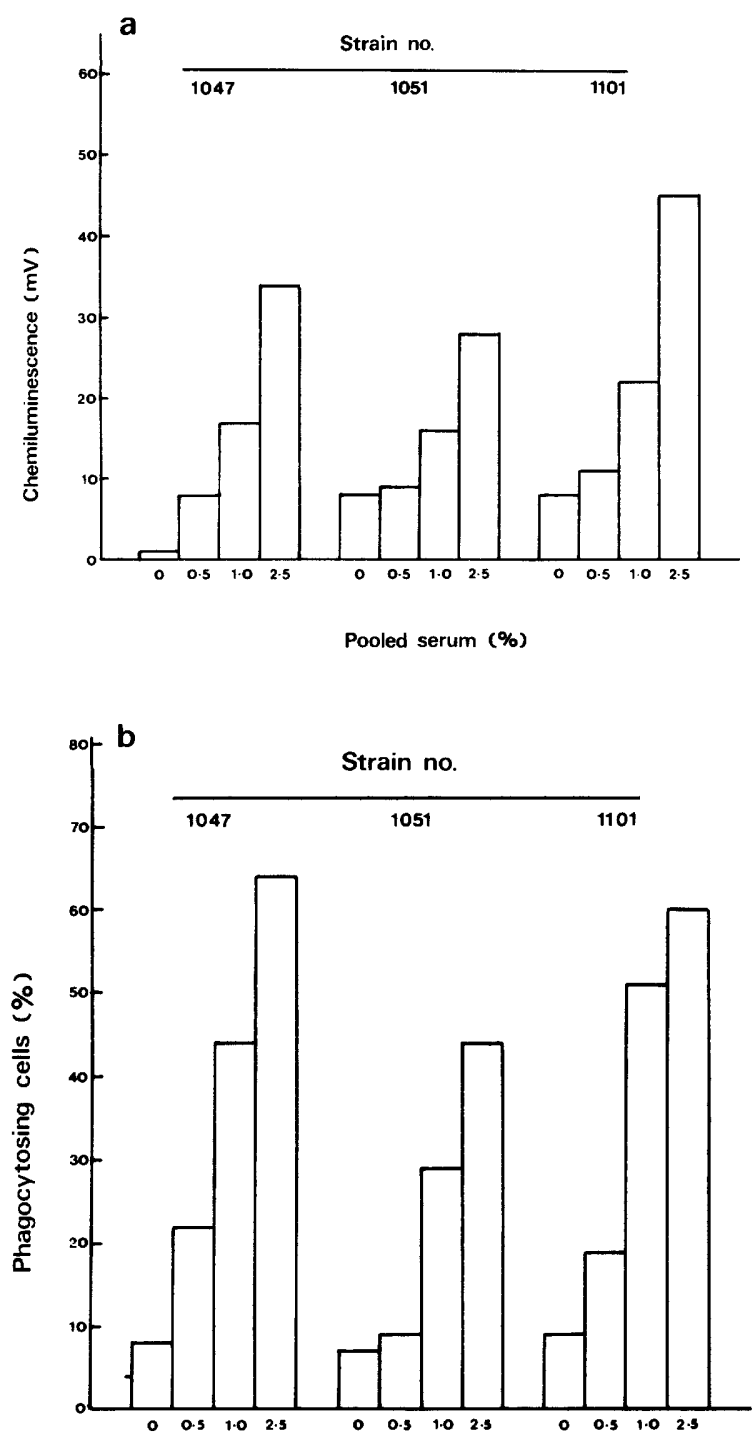

Pooled serum (\%)

Fig. 1. Effect of serum concentration on total uptake of $S$. epidermidis strains, measured by: (a) luminol-dependent chemiluminescence and (b) microscopy.

epidermidis strain 1101 reduced the opsonic capacity of $2.5 \%$ NHS to a greater extent than that of $10 \%$ NHS (fig. 3). Even with $10 \%$ NHS the effect of absorption was to slow the rate of opsonisation (fig. 4); thus, after opsonisation for 5 min, the test strain of S. epidermidis (no. 1101) was poorly taken up. Only after opsonisation for $15 \mathrm{~min}$ did the uptake approach that after opsonisation with unabsorbed $10 \%$ NHS.

Neither HHS nor the IgG preparation showed any opsonic activity against $S$. epidermidis on their own. Even IgG at $10 \mathrm{mg} / \mathrm{ml}$ had no effect. However, when complement was added the opsonic effect of both heated serum and purified IgG was enhanced (table II). For a given IgG concentration, HHS was a more effective opsonin than purified IgG when combined with complement.

Peritoneal-dialysis effluents from 18 uninfected patients were examined; in all samples the content of complement (C3c) and IgG was low, and none showed any significant opsonic activity (table III). $S$. epidermidis grew poorly in peritoneal-dialysis fluid but very much better in dialysis effluent; its opsonic requirements when grown in the latter were similar to those when grown in Brain Heart Infusion Broth (fig. 5).

\section{Discussion}

The $18 \mathrm{~S}$. epidermidis strains investigated belonged to several different biotypes and had been isolated from a variety of sites in the human body. We found no difference in their basic opsonic requirements, all requiring both complement and antibody. Blocking the classical pathway of complement activation had little effect on opsonisation. Serum concentrations as low as $1 \%$ provided near optinal opsonisation of $S$. epidermidis, but below this opsonic activity dropped sharply.

Verhoef et al. (1977) examined the opsonic requirements of three $S$. epidermidis strains using $10 \%$ pooled NHS. Two of the three showed the same pattern that we found, while the third was well opsonised by HHS. Keane and Peterson (1984) examined four strains and found no differences in opsonic requirements. A serum concentration of $1 \%$ was the lowest that gave optimal opsonisation: HHS at a concentration of $20 \%$ was as good an opsonin as NHS, suggesting an antibody-mediated effect independent of complement. Other publications by workers of this group (Keane et al., 1984; Verbrugh et al., 1984), who used $10 \%$ HHS, also suggest antibody-mediated complement-independent opsonisation, but it is not clear whether the same $S$. epidermidis strain was used on each occasion. Keane, Verbrugh and their colleagues measured the uptake of radiolabelled staphylococci while we used chemiluminescence and microscopy, but it is unlikely that this would account for our differing results with NHS and HHS. Although we examined more strains of $S$. epidermidis than they did, some degree of heterogeneity of properties is to be expected.

There is general agreement that a serum concentration of $0.5-1.0 \%$ is the lowest that will give good opsonisation of $S$. epidermidis. Other workers have also shown that the content of $\mathrm{C} 3$ and $\mathrm{IgG}$ in 


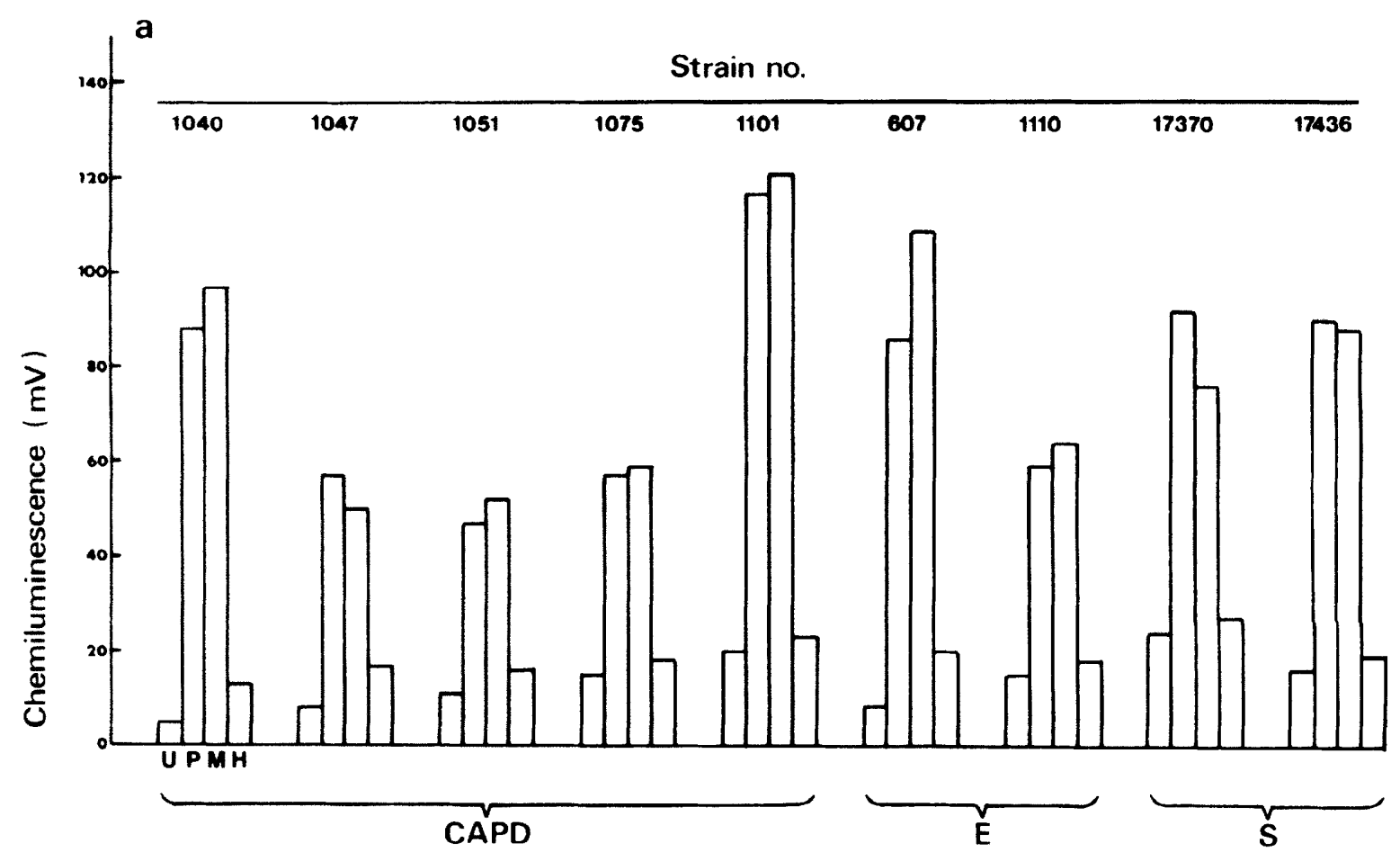

b

Strain no.

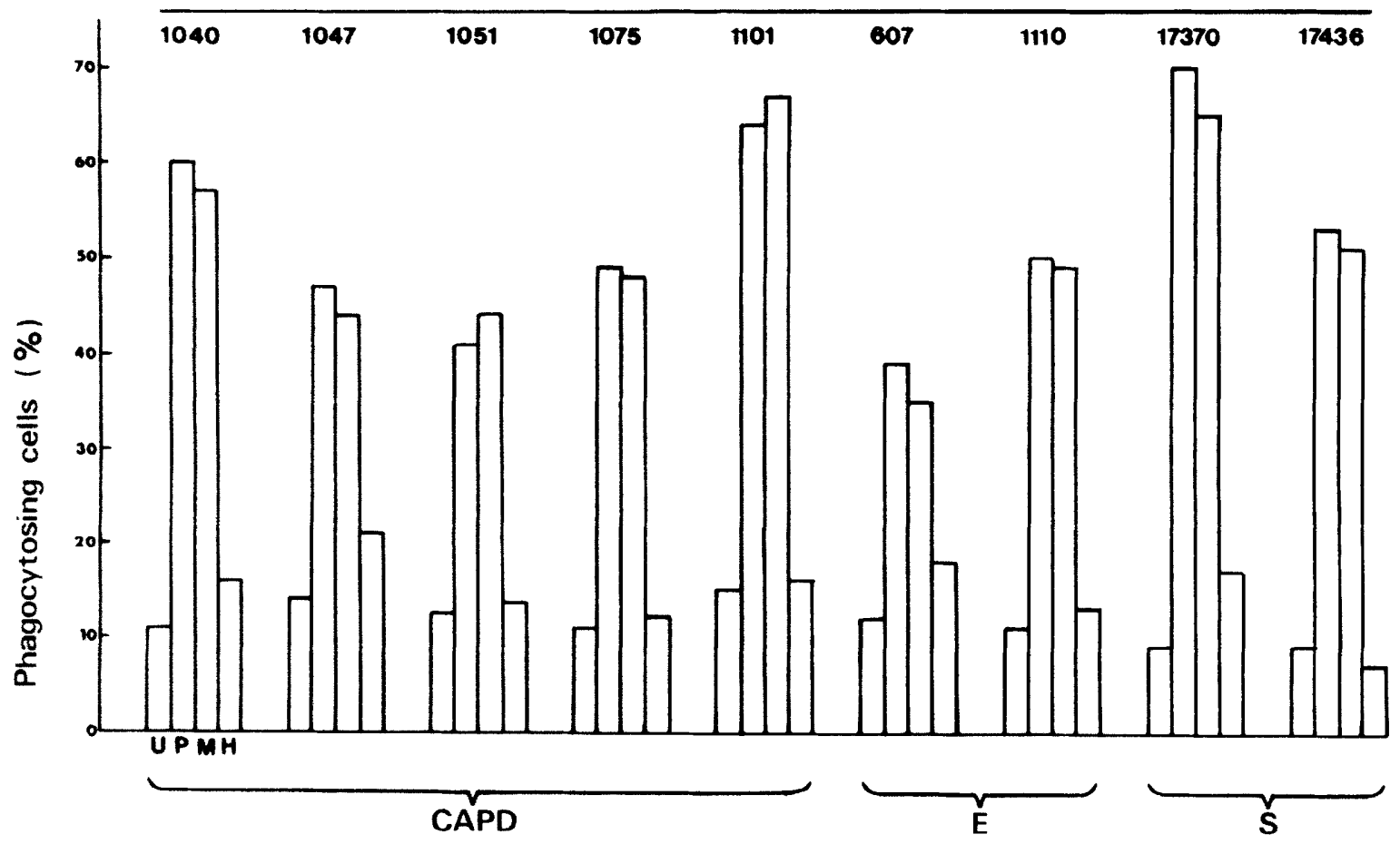

Fig. 2. Uptake of $S$. epidermidis strains: $U=$ unopsonised; $P=$ opsonised with $2.5 \%$ normal human serum; $M=o p s o n i s e d$ with serum chelated with MgEGTA; $\mathrm{H}=$ opsonised with heat-inactivated serum; measured by (a) luminol-dependent chemiluminescence and (b) microscopy. Strains from: $C A P D=$ peritoneal fluid of patients on continuous ambulatory peritoneal dialysis; $E=b l o o d ~ o f$ endocarditis patients; $\mathrm{S}=$ normal human skin. 

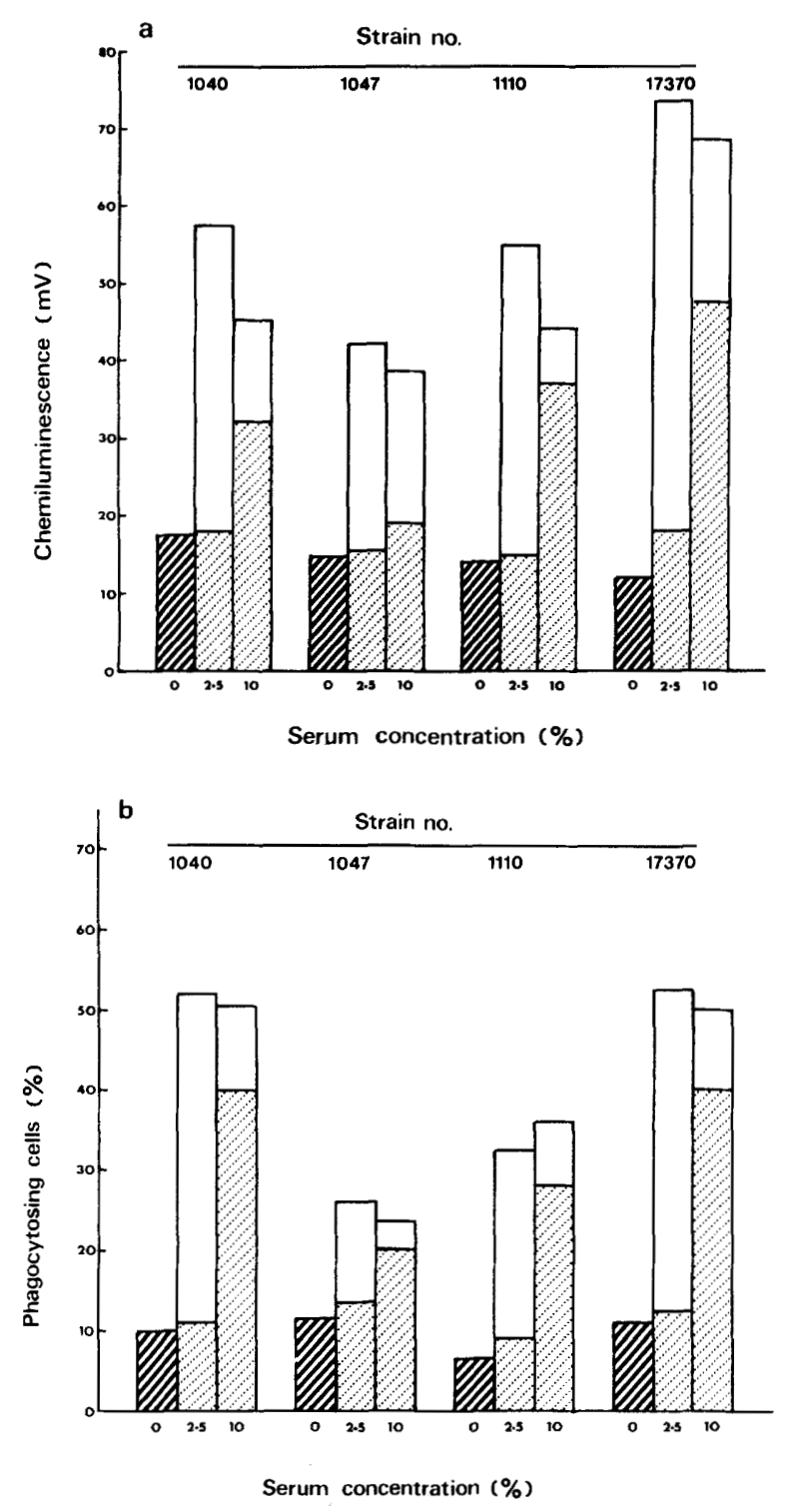

Fig. 3. Effect of opsonisation with $2.5 \%$ and $10 \%$ normal human serum, and with these sera after absorption with $S$. epidermidis strain 1101 , on the uptake of $S$. epidermidis strains, measured by (a) luminol-dependent chemiluminescence and (b) microscopy. = unopsonised bacteria; = bacteria opsonised with normal human serum or absorbed serum; $\square=$ bacteria opsonised with normal human serum only.

peritoneal-dialysis effluent from uninfected patients is very low (Verbrugh et al., 1983; Keane et al., 1984). Verbrugh et al. (1983) found that some peritoneal-dialysis effluents from uninfected CAPD patients did have opsonic activity for S. epidermidis and that there was a good correlation between this and $\mathrm{IgG}$ and $\mathrm{C} 3$ levels. The mean concentrations of $\operatorname{IgG}(108 \mathrm{mg} / \mathrm{L})$ and $\mathrm{C} 3(28 \mathrm{mg} / \mathrm{L})$ that they found in

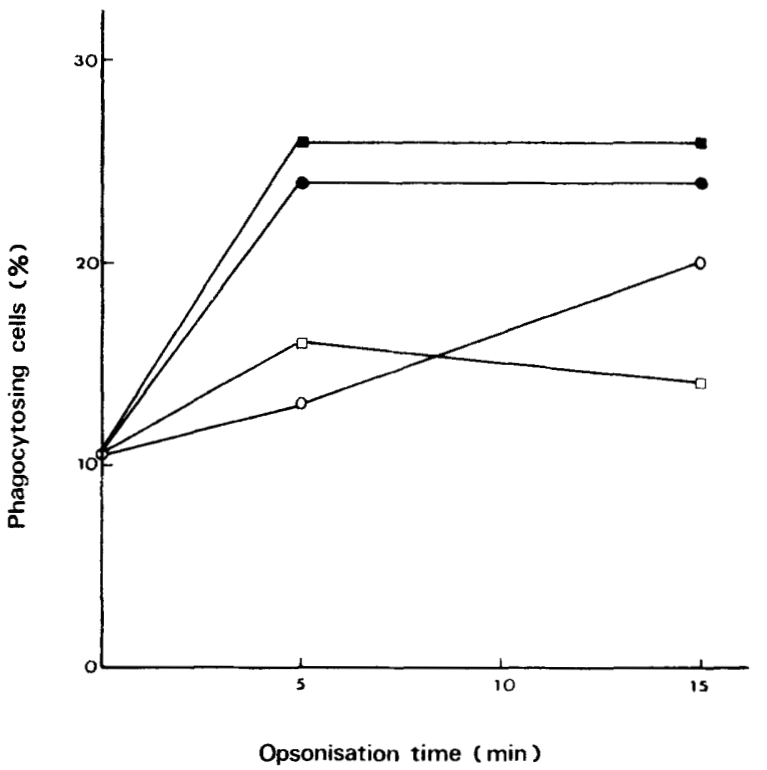

Fig. 4. Effect of time of opsonisation with: $-2.5 \%$ NHS; $\square 2.5 \%$ absorbed serum; $10 \%$ NHS; and $\bigcirc 10 \%$ absorbed serum on uptake of $S$. epidermidis strain 1101 .

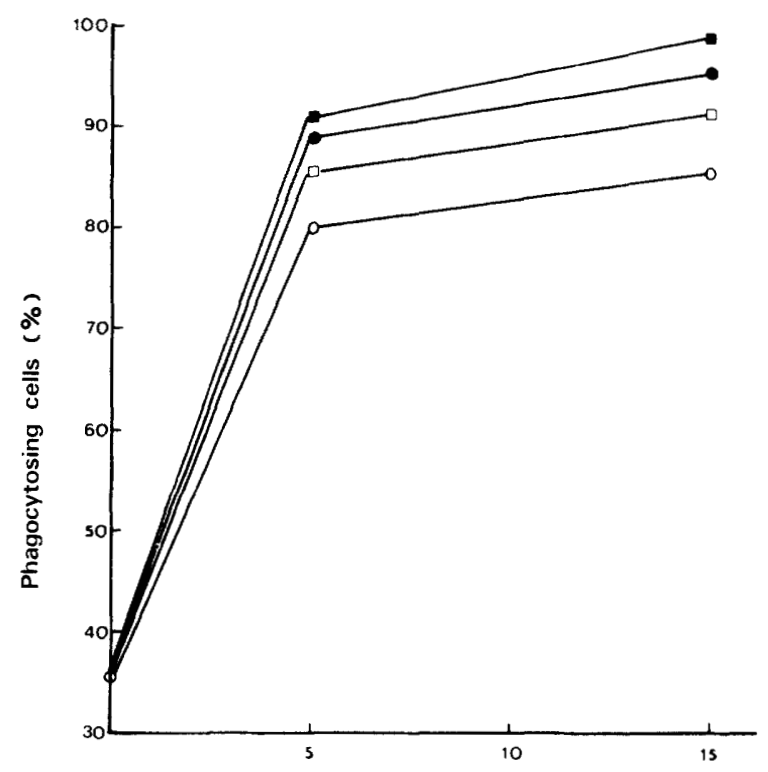

Opsonisation time $(\mathrm{min})$

Fig. 5. Effect of growth of S. epidermidis strain 1101 in Brain Heart Infusion Broth (closed symbols) or peritoneal-dialysis effluent (open symbols) on opsonisation by $2.5 \%$ NHS (squares) and $2 \cdot 5 \% \mathrm{MgEGTA}$-chelated serum (circles).

effluents with good opsonic activity were higher than the mean levels $(45 \mathrm{mg} / \mathrm{L}$ and $3.7 \mathrm{mg} / \mathrm{L}$ respectively) that we found in our 18 patients. In fact our levels were similar to those that Verbrugh 
Table II. Opsonic activity of heated human serum (HHS) and of IgG for $S$. epidermidis strain 1101 in the presence and absence of complement

\begin{tabular}{lcc|cc}
$\begin{array}{l}\text { Source of } \\
\text { immunoglobulin }\end{array}$ & $\begin{array}{c}\text { Concentration } \\
\text { of lgG } \\
(\mathrm{mg} / \mathrm{ml})\end{array}$ & Complement* & $\begin{array}{c}\text { Chemiluminescence } \\
(\mathrm{mV})\end{array}$ & $\begin{array}{c}\text { Percentage of } \\
\text { phagocytosis }\end{array}$ \\
$\ldots$ & 0 & - & 8 & 10 \\
$\ldots$ & 0 & + & 12 & 10 \\
HHS & $0 \cdot 3$ & - & 11 & 12 \\
HHS & $1 \cdot 2$ & - & 13 & 13 \\
HHS & $2 \cdot 4$ & - & 15 & 12 \\
IgG (Sandoglobulin) & $1 \cdot 0$ & + & 10 & 19 \\
HHS & $0 \cdot 3$ & + & 22 & 30 \\
HHS & $1 \cdot 2$ & + & 60 & 38 \\
HHS & $2 \cdot 4$ & + & 10 & 24 \\
IgG (Sandoglobulin) & $0 \cdot 3$ & 1.0 & 16 & 11 \\
IgG (Sandoglobulin) & $1 \cdot 0$ & + & &
\end{tabular}

* Baby rabbit serum $\left(10^{\circ}{ }_{0}\right):+=$ added; $-=$ not added.

Table III. IgG and C3c content and opsonic activity of peritoneal-dialysis fluid from 18 uninfected patients, and of pooled normal human serum (NHS)

\begin{tabular}{|c|c|c|c|c|c|}
\hline \multicolumn{3}{|c|}{ Opsonin } & \multicolumn{3}{|c|}{ Phagocytic activity } \\
\hline Description & $\begin{array}{l}\mathrm{IgG}(\mathrm{mg} / \mathrm{L}): \\
\text { mean (range) }\end{array}$ & $\begin{array}{l}\mathrm{C} 3 \mathrm{c}(\mathrm{mg} / \mathrm{L}): \\
\text { mean (range) }\end{array}$ & $\begin{array}{c}\text { Number of } \\
\text { tests }\end{array}$ & $\begin{array}{l}\text { Chemiluminescence } \\
\qquad(\mathrm{mV}): \\
\text { mean (range) }\end{array}$ & $\begin{array}{l}\text { Percentage } \\
\text { phagocytosis } \\
\text { mean (range) }\end{array}$ \\
\hline Dialysis effluent* & $45(5-115)$ & $3 \cdot 7(1 \cdot 1-8 \cdot 2)$ & 54 & $15(3-49)$ & $11(4-18)$ \\
\hline $2 \cdot 5_{0}^{\circ}$ NHS & 300 & 14 & 54 & $92(37-237)$ & $49(2876)$ \\
\hline None & $\ldots$ & $\ldots$ & 54 & $13(5-24)$ & $9(3-15)$ \\
\hline
\end{tabular}

* Undiluted.

found in effluents with no opsonic activity. This at least supports the view that differences in the techniques employed were not responsible for the lack of conformity between their results and ours.

Work to date has concentrated on the opsonic activity of dialysis effluents from uninfected patients and the use of this as an indicator of future infection (Keane et al., 1984). What is less clear is how rapidly IgG.C3 and PMN enter the peritoneal cavity during the earliest phases of infection. Differences at this stage rather than before infection may be crucial in deciding whether infection is controlled early or allowed to develop. Verbrugh et al. (1984) have shown that at least $10^{6}$ phagocytic cells $/ \mathrm{ml}$ are needed to control bacterial growth. We are now studying the early phase of peritonitis before antibiotics are used to see if cells, IgG and complement enter at different rates in different individuals.

The major target for opsonic antibody in $S$. aureus is peptidoglycan. Cell-wall ribitol teichoic acid does not appear to be concerned in this (Wheat et al., 1974; Peterson et al., 1978). Strains of $S$. aureus containing protein $\mathrm{A}$ are well opsonised in IgG-deficient sera (Verhoef et al., 1977). S. epidermidis does not contain protein $\mathrm{A}$ and its cell-wall teichoic acid contains glycerol but not ribitol. The peptidoglycan of $S$. epidermidis differs from that of $S$. aureus only in the amino-acid content of the interpeptide cross links between the glycopeptide chains. In $S$. epidermidis, some of the glycine residues are replaced by L-serine, but the position of the serine substitution is not constant (Schliefer, 1983). The structural basis for heterogeneity of opsonic requirements in normal human serum is not known. Absorption studies with purified cell-wall components might clarify the point. Keane and Peterson (1984) reported that absorption with $S$. epidermidis peptidoglycan did remove the opsonic activity from serum, but provided no data.

In addition to cell-wall components, some strains 
of $S$. epidermidis produce extracellular slime. This may play an important role in adherence to catheters and prostheses (Bayston and Penny, 1972; Peters et al., 1982). Extracellular material of this type might interfere with opsonisation and phagocytosis, thus acting as a virulence factor for $S$. epidermidis in the peritoneal cavity. We have started to examine the effects of slime on opsonisation and phagocytosis. There are, however, technical problems. The slime does not form a well defined extracellular layer and is easily lost from the surface of the staphylococci as they are being prepared for phagocytosis studies. We have not yet attempted to purify the slime from $S$. epidermidis.

Although we could find no differences in the

\section{REFERENCES}

Baird-Parker A C 1963 A classification of micrococci and staphylococci based on physiological and biochemical tests. Journal of General Microbiology 30:409-427.

Bayston R, Penny S R 1972 Excessive production of mucoid substance in staphylococcus SIIA: a possible factor in colonisation of Holter shunts. Developmental Medicine and Child Neurology 14: (Suppl 27) 25-28.

Duwe A K, Vas S I, Weatherhead J W 1981 Effects of the composition of peritoneal dialysis fluid on chemiluminescence, phagocytosis and bactericidal activity in vitro. Infection and Immunity 33:130-135.

Easmon C S F, Glynn A A 1976 Comparison of subcutaneous and intraperitoneal staphylococcal infections in normal and complement-deficient mice. Infection and Immunity 13:399406.

Hastings M J G, Easmon C S F 1981 Variations in the opsonic requirements of group B streptococcus type III. British Journal of Experimental Pathology 62:519-525.

Keane W F, Comty C M, Verbrugh H A, Peterson P K 1984 Opsonic deficiency of peritoneal dialysis effluent in continuous ambulatory peritoneal dialysis. Kidney International 25:539-543.

Keane W F, Peterson P K 1984 Host defence mechanisms of the peritoneal cavity and continuous ambulatory peritoneal dialysis. Peritoneal Dialysis Bulletin, 4:122-127.

Marples RR, Hone R, Notley C M, Richardson J F, CreesMorris J A 1978 Investigation of coagulase-negative staphy- opsonic requirements of $S$. epidermidis from various sites, the literature suggests that at least some strains do not require complement for opsonisation. As far as infection is concerned the main point is whether such variation could be linked to virulence. With the exception of slime production, which merits further investigation, there seems no evidence to suggest that certain strains of $S$. epidermidis are more likely to cause peritonitis in CAPD by virtue of their greater resistance to opsonisation and phagocytic killing.

We thank the medical and nursing staff of the Dialysis Unit, St Mary's Hospital, for their help with this project and the National Kidney Research Fund for financial support.

lococci from infections in surgical patients. Zentralblatt für Bakteriologie Mikrobiologie und Hygiene, I. Abt. Originale A 241, 140-156.

Peters G, Locci R, Pulverer G 1982 Adherence and growth of coagulase-negative staphylococci on surfaces of intravenous catheters. Journal of Infectious Diseases 146:479-482.

Peterson P K, Wilkinson B J, Kim Y, Schmeling D, Douglas S D, Quie P G 1978 The key role of peptidoglycan in the opsonization of Staphylococcus aureus. Journal of Clinical Investigation 61:597-609.

Schliefer K H 1983 The cell envelope. In: Easmon C S F, Adlam C (eds) Staphylococci and staphylococcal infections, vol. 2. Academic Press Inc Ltd, London, pp 385-428.

Verbrugh H A, Keane W F, Hoidal J R, Freiberg M R, Elliott G R, Peterson P K 1983 Peritoneal macrophages and opsonins: antibacterial defense in patients undergoing chronic peritoneal dialysis. Journal of Infectious Diseases 147:10181029.

Verbrugh H A, Keane W F, Conroy W E, Peterson P K 1984 Bacterial growth and killing in chronic ambulatory peritoneal dialysis fluids. Journal of Clinical Microbiology 20:199203.

Verhoef J, Peterson P K, Kim Y, Sabath L D, Quie P G 1977 Opsonic requirements for staphylococcal phagocytosis. Immunology 33:191-197.

Wheat L J, Humphreys D W, White A 1974 Opsonization of staphylococci by normal human sera: the role of antibody and heat-labile factors. Journal of Laboratory and Clinical Medicine 83:73-78. 